\title{
Estimasi Nilai Hydraulic dan Solid Loading Rate Tipe Pengendapan Diskrit dan Flok Pada Proses Lumpur Aktif Untuk Pengolahan Limbah Cair Industri Kertas
}

\author{
Fatihaturrizky Amelia, Owen Jacob Notonugroho, Satyanto Krido Saptomo, Allen Kurniawan* \\ Departemen Teknik Sipil dan Lingkungan, Fakultas Teknologi Pertanian, Institut Pertanian Bogor, Gedung FATETA, Kampus IPB \\ Dramaga, Bogor, Jawa Barat, 16680;
}

\begin{abstract}
ABSTRAK
Beban limbah cair industri kertas meningkat seiring dengan peningkatan produksi kertas di Indonesia. Konsentrasi COD berkisar antara 8.300-45.384 mg/L O $\mathrm{O}_{2}$ dan TSS sebesar $41.000 \mathrm{mg} / \mathrm{L}$. Salah satu upaya untuk mengurangi beban COD dan TSS di dalam limbah cair industri kertas adalah dengan memanfaatkan proses lumpur aktif. Penelitian ini difokuskan pada pengaruh proses sedimentasi di dalam unit lumpur aktif untuk mereduksi COD dan TSS. Penelitian ini juga mencakup analisis dua tipe pengendapan, yaitu pengendapan partikel diskrit dan pengendapan flok. Tujuan utama penelitian ini untuk mengestimasi nilai hydraulic loading rate dan solid loading rate serta rekomendasi dimensi unit sedimentasi lumpur aktif. Penelitian ini meliputi kegiatan monitoring kinerja proses dengan tiga variasi waktu detensi (HRT). Beberapa variabel yang diperhatikan untuk mencapai tujuan penelitian ini, antara lain kecepatan pengendapan bebas $(v)$, percepatan gravitasi $(g)$, massa jenis partikel $\left(\rho_{\mathrm{s}}\right)$, massa jenis fluida $(\rho)$, diameter partikel $(d)$, dan koefisien penarikan atau drag coefficient $\left(C_{\mathrm{d}}\right)$. Pengukuran reduksi COD mengacu pada SNI 6989.2:2009 dan pengukuran reduksi TS mengacu pada SNI 06-6989.26-2005. Penelitian ini menunjukkan bahwa kecepatan pengendapan discrete particle settling tergantung pada karakteristik satuan partikel berdasarkan diameter partikel. Kecepatan pengendapan flocculant settling tergantung pada pengaruh interaksi partikel dalam pembentukan flok atau gumpalan beberapa entitas partikel. Jika ditinjau dari nilai umur lumpur (SLR), HRT 8 jam dan HRT 12 jam menunjukkan kondisi under loaded pada unit sedimentasi. Sementara itu, nilai HLR dan SLR pada HRT 6 jam telah memenuhi rentang kriteria desain lumpur aktif. Dengan demikian, desain terbaik untuk unit sedimentasi sekunder lumpur aktif, yaitu HRT 6 jam dengan HLR sebesar 42,16 m³ $/ \mathrm{m}^{2}$ hari, SLR sebesar 102,45 kg/m²hari dan rata-rata reduksi padatan total mencapai 89,26\%.
\end{abstract}

Kata kunci: hydraulic loading rate, lumpur aktif, pengendapan diskrit, pengendapan flok, umur lumpur, dan waktu detensi.

\begin{abstract}
The influence of paper production affect simultenously to the increase of pulp and paper wastewater in Indonesia. The COD concentration ranged from 8,300-45,384 $\mathrm{mg} / \mathrm{L} \mathrm{O}_{2}$ and TSS was 41,000 mg/L. Reducing COD and TSS concentrations in the paper industry wastewater is to utilize by using activated sludge processes. This research was focused on the effect of sedimentation process in activated sludge to reduce COD and TSS. This research also included the analysis of two types of deposition, namely discrete particle settling and floc settling. Main objective this research was directed at determining the value of the hydraulic loading rate and solid loading rate as well as recommendations for the dimensions of the activated sludge sedimentation unit. This research included monitoring of process performance with three variations of detention time (HRT). There were several variables that are considered to achieve the objectives of this study, including free deposition velocity $(v)$, acceleration due to gravity $(g)$, particle density $\left(\rho_{\mathrm{s}}\right)$, fluid density $(\rho)$, particle diameter $(d)$, and drag coefficient. coefficient $\left(C_{\mathrm{d}}\right)$. The COD and TS reduction measurement refered to SNI 6989.2:2009 and SNI 06-6989.26-2005, respectively. This study showed that the speed of discrete particle settling depends on the characteristics of the particle unit as seen from the particle diameter. The deposition rate of flocculant settling depends on the effect of particle interactions in the formation of flocs or agglomerates of several particle entities. When viewed from the SLR value obtained, the 8-hour HRT and 12-hour HRT indicated that the sedimentation unit was in an under-loaded condition. Meanwhile, the HLR and SLR values at HRT 6 hours complied the activated sludge design criteria.. Thus, the best design for the activated sludge secondary sedimentation unit was HRT 6 hours with an HLR of $42,16 \mathrm{~m}^{3} / \mathrm{m}^{2} \mathrm{day}$, an SLR of $102,45 \mathrm{~kg} / \mathrm{m}^{2}$ day and an average total solids reduction of $89,26 \%$.
\end{abstract}

Keywords: activated sludge, discrete settling, floc settling, hydraulic loading rate, hydraulic retention time, and solid retention time.

Sitasi: Amelia, F., Nutonugroho, O.J., Saptomo, S.K., Kurniawan, A. (2022). Estimasi Nilai Hydraulic dan Solid Loading Rate Tipe Pengendapan Diskrit dan Flok Pada Proses Lumpur Aktif Untuk Pengolahan Limbah Cair Industri Kertas. Jurnal Ilmu Lingkungan, 22(3),445-456, doi: $10.14710 / \mathrm{jil} .20 .3 .445-456$

\section{Pendahuluan}

Industri kertas menjadi salah satu industri penghasil air limbah dengan debit yang besar (Rosidi dan Razif, 2017). Penggunaan air dalam industri kertas menghabiskan $60 \mathrm{~m}^{3}$ setiap ton kertas (Klidi et al. 2019). Umumnya, parameter air limbah industri kertas

\footnotetext{
* Penulis korespondensi: allenkurniawan@apps.ipb.ac.id
} 
mengacu pada nilai Chemical Oxygen Demand (COD). Selain itu, padatan yang tersuspensi dalam air limbah industri kertas dipantau dari nilai Total Suspended Solid (TSS). Nilai COD air limbah industri kertas sebesar 8.300-45.384 mg/L $\mathrm{O}_{2}$ dan TSS sebesar 41.000 mg/L (Rosidi dan Razif, 2017). Peningkatan nilai COD menyebabkan penurunan konsentrasi oksigen di dalam air. Selain itu, kandungan TSS yang tinggi dapat menghambat laju fotosintesis biota air (Fathiyah et al. 2017). Apabila limbah cair industri kertas langsung dialirkan ke badan air, maka kemampuan pemulihan lingkungan secara alami (natural selfpurification) akan terganggu akibat beban polutan berlebih di dalam media air, khususnya COD dan TSS.

Upaya untuk mereduksi kandungan pencemar dalam air limbah industri kertas dapat diterapkan proses pengolahan air limbah konvensional secara biologis melalui unit lumpur aktif. Pengolahan air limbah secara biologis memiliki nilai efisiensi dan efektivitas yang baik (Assadi et al,. 2020). Pengolahan limbah cair secara biologis mampu mengurai 50\% material organik menjadi $\mathrm{CO}_{2}$ dan mengonversi $50 \%$ sisa material organik menjadi biomassa (Sarah, 2005). Lumpur aktif menjadi salah satu bentuk dari proses pengolahan secara biologis dengan kombinasi unit aerasi dengan sedimentasi. Unit aerasi menjadi tempat untuk mikroorganisme berkembangbiak dan mendegradasi substrat air limbah seperti COD. Jumlah mikroorganisme yang meningkat dalam unit aerasi akan menyebabkan nilai Total Solid (TS) meningkat sehingga dibutuhkan unit sedimentasi sekunder untuk mendegradasi kadar TS dalam konfigurasi lumpur aktif (Sarah, 2005).

Kinerja lumpur aktif dapat ditentukan berdasarkan variabel operasional, seperti waktu detensi (HRT), hydraulic loading rate (HLR), dan solid loading rate (SLR). Penerapan waktu detensi pada unit sedimentasi berperan pada tingkat efisiensi konsentrasi padatan di dalam proses sedimentasi (Saleh et al. 2015), sedangkan HLR dan SLR berperan dalam penentuan dimensi unit sedimentasi sekunder. Variasi HRT dilakukan secara langsung terhadap reaktor lumpur aktif, sedangkan karakter kecepatan pengendapan limbah cair dapat dipelajari melalui pemodelan tipe sedimentasi. Secara garis besar, tipe sedimentasi terbagi menjadi empat (4), yaitu discrete particle, flocculant settling, hindered settling, dan compression settling. Karakter setiap tipe pengendapan bergantung pada konsentrasi padatan dan kecenderungan interaksi antar padatan (Lee dan Lin 2007). Proses sedimentasi berdasarkan sifat satuan partikel dipantau dari tipe sedimentasi discrete particle (pengendapan diskrit), sedangkan tipe flocculant settling (pengendapan flok) diaplikasikan untuk mengetahui proses pengendapan akibat kecenderungan padatan limbah cair untuk menggumpal. Kedua tipe sedimentasi tersebut digunakan untuk menentukan karakter padatan dalam limbah cair industri kertas ketika mengalami proses pengendapan. Pengendapan diskrit dan flok menjadi fokus utama dalam penelitian ini untuk menganalisis proses pengendapan yang tejadi akibat interaksi partikel diskrit dan flok limbah cair industri kertas. Dengan demikian, penelitian ini diharapkan mampu memberikan rekomendasi kriteria desain yang mencakup nilai HRT, SLR, HLR, serta opsi dimensi pengolahan lumpur aktif berdasarkan pengamatan terhadap proses sedimentasi discrete particle dan dlocculant settling untuk limbah cair industri kertas.

\section{Metodologi}

Prosedur kerja pada penelitian ini terbagi menjadi tahap persiapan, tahap monitor kinerja proses, dan tahap analisis data. Penelitian ini dilakukan di Laboratorium Limbah Padat dan B3, Institut Pertanian Bogor. Proses pengukuran parameter air limbah dalam penelitian ini mengacu pada standar pengujian SNI 06-6989.26-2005 tentang Cara Uji Kadar Padatan Total Secara Gravimetri untuk memperoleh data TS dan SNI 6989.2:2009 tentang Cara Uji Kebutuhan Oksisgen Kimiawi dengan Refluks Tertutup Secara Spektrofotometri untuk memperoleh data COD.

\subsection{Tahap persiapan}

Tahap persiapan diawali dengan merancang reaktor lumpur aktif dan penentuan jenis air limbah. Reaktor lumpur aktif dibuat dengan bentuk rektangular dengan masing-masing unit aerasi dan sedimentasinya memiliki panjang sebesar $35,8 \mathrm{~cm}$, lebar sebesar 21,9 cm, dan tinggi sebesar $25,8 \mathrm{~cm}$. Air limbah sebagai substrat diperoleh dari efluen unit ekualisasi, sedangkan biomassa diperoleh dari aliran resirkulasi lumpur aktif pada salah satu IPAL sebuah industri kertas di Bandung, Jawa Barat. Selanjutnya, reaktor disimulasikan dengan melalui pemantauan konsentrasi COD dan TS secara kontinu.

\subsection{Tahap Monitor Kinerja Proses}

Konsentrasi COD influen air limbah dikontrol pada kisaran 200-400 $\mathrm{mg} / \mathrm{L}$ melalui proses pengenceran untuk mengurangi laju beban organik. Selain itu, nilai TS dalam unit aerasi dikontrol pada kisaran 3000-4000 mg/L (Liu et al. 2020). Waktu detensi (HRT) operasional reaktor lumpur aktif dijalankan selama 6, 8, dan 12 jam secara simultan. Setiap variasi waktu detensi dijalankan selama 15 hari diikuti dengan pemantauan kinerja proses.

Kontrol variasi HRT dilakukan dengan melakukan perubahan debit di unit lumpur aktif. Debit influen aerasi dipengaruhi dari debit air limbah industri kertas dan resirkulasi sehingga debit efluen aerasi/influen sedimentasi akan sama dengan debit influen aerasi (Tabel 1). Pemantauan terhadap sedimentasi dapat dilakukan setelah debit influen telah dijalankan konstan. Pengukuran data terhadap unit sedimentasi dilakukan dengan membuat pemodelan discrete particle settling. 
Variabel yang terkait dengan perhitungan model discrete particle, yaitu kecepatan pengendapan bebas $(v)$, percepatan gravitasi $(g)$, massa jenis partikel $\left(\rho_{\mathrm{s}}\right)$, massa jenis fluida $(\rho)$, diameter partikel $(d)$, dan koefisien penarikan atau drag coefficient $\left(C_{\mathrm{d}}\right)$. Berdasarkan Tabel 2, nilai drag coefficient bergantung pada bilangan Reynolds di dalam aliran fluida. Estimasi bilangan Reynolds aliran fluida dapat dihitung dengan Persamaan 2. Setelah nilai drag coefficient diperoleh, kecepatan pengendapan bebas $(v)$ untuk setiap discrete particle dalam fluida dapat dihitung melalui Persamaan (1).

Selanjutnya, pengukuran data flocculant settling dilakukan selama 75 menit untuk satu kali pengujian. Pengumpulan data flocculant settling dilakukan dengan pengambilan padatan total melalui lima (5) variasi kedalaman uji dan lima (5) variasi durasi pengendapan. Rentang durasi pengendapan dalam pengujian flocculant settling berada antara 15 menit hingga 75 menit. Selain itu, rentang kedalaman uji berada antara kedalaman 5,16-25,8 cm dari ketinggian awal kolom sampel uji.

Rentang kedalaman pengujian flocculant settling dipilih berdasarkan ketersediaan kolom uji dengan ketinggian maksimum sebesar $36,6 \mathrm{~cm}$. Persen reduksi padatan total flocculant settling dikonversi menjadi kurva isokonsentrasi. Estimasi total reduksi (TR) padatan total pada kedalaman tertentu dan durasi pengendapan tertentu. Variabel yang diperhitungkan dalam flocculant settling, yaitu jarak vertikal antar kurva isokonsentrasi $\left(\Delta h_{1}, \Delta h_{2}, \ldots, \Delta h_{n}\right)$, persentase reduksi kurva isokonsentrasi $\left(R_{1}, R_{2}, \ldots, R_{n-1}\right)$, dan kedalaman uji $\left(h_{o}\right)$. Pengamatan flocculant settling diarahkan pada penentuan kecepatan pengendapan dan surface loading rate (SLR) atau hydraulic loading rate (HLR) melalui Persamaan (5) dan (6).

$$
\begin{aligned}
& C_{\mathrm{u}} H_{\mathrm{u}}=C_{\mathrm{o}} H_{\mathrm{o}} \\
& A=\frac{Q t_{u}}{H_{\mathrm{o}}} \\
& \mathrm{SLR}=\frac{Q C_{\mathrm{o}}}{A} \\
& \text { HLR }=\frac{Q}{A}
\end{aligned}
$$$$
v=\left(\frac{4 g\left(\rho_{s}-\rho\right) d}{3 C_{d} \rho}\right)^{1 / 2}
$$$$
\text { Bilangan Reynolds }=\frac{v d \rho}{\mu}
$$

Keterangan:

$v=$ kecepatan pengendapan bebas $(\mathrm{m} / \mathrm{s})$

$g=$ percepatan gravitasi $\left(\mathrm{m} / \mathrm{s}^{2}\right)$

$\rho_{\mathrm{s}}=$ massa jenis partikel $\left(\mathrm{kg} / \mathrm{m}^{3}\right)$

$\rho=$ massa jenis fluida $\left(\mathrm{kg} / \mathrm{m}^{3}\right)$

$d=$ diameter partikel $\left(\mathrm{kg} / \mathrm{m}^{3}\right)$

$C_{\mathrm{d}}=$ koefisien penarikan atau drag coefficient

$\mathrm{SLR}=$ solid loading rate $\left(\mathrm{kg} / \mathrm{m}^{2}\right.$.hari $)$

$\mathrm{HLR}=$ hydraulic loading rate $\left(\mathrm{m}^{3} / \mathrm{m}^{2}\right.$.hari $)$

\begin{tabular}{|c|c|c|c|c|}
\hline \multirow{2}{*}{ Parameter } & \multirow{2}{*}{ Simbol } & \multicolumn{3}{|c|}{ HRT } \\
\hline & & 6 jam & 8 jam & 12 jam \\
\hline Debit tangki aerasi (L/hari) & $Q_{\mathrm{p}}$ & 16,00 & 12,00 & 8,00 \\
\hline Debit efluen tangki sedimentasi (L/hari) & $Q_{\mathrm{a}}$ & 28,00 & 21,00 & 14,00 \\
\hline Debit aliran bawah (L/hari) & $Q_{\mathrm{s}}$ & 14,95 & 9,11 & 6,99 \\
\hline Debit sisa lumpur (L/hari) & $Q_{\text {us }}$ & 13,05 & 11,89 & 7,31 \\
\hline Debit resirkulasi lumpur (L/hari) & $Q_{w}$ & 1,05 & 8,96 & 4,11 \\
\hline
\end{tabular}

$C_{\mathrm{u}}=$ konsentrasi padatan pada kedalaman $H_{\mathrm{u}}(\mathrm{mg} / \mathrm{L})$

$C_{\mathrm{o}}=$ konsentrasi padatan pada kedalaman $H_{\mathrm{o}}(\mathrm{mg} / \mathrm{L})$

Tabel 1. Rekapitulasi operasional lumpur aktif

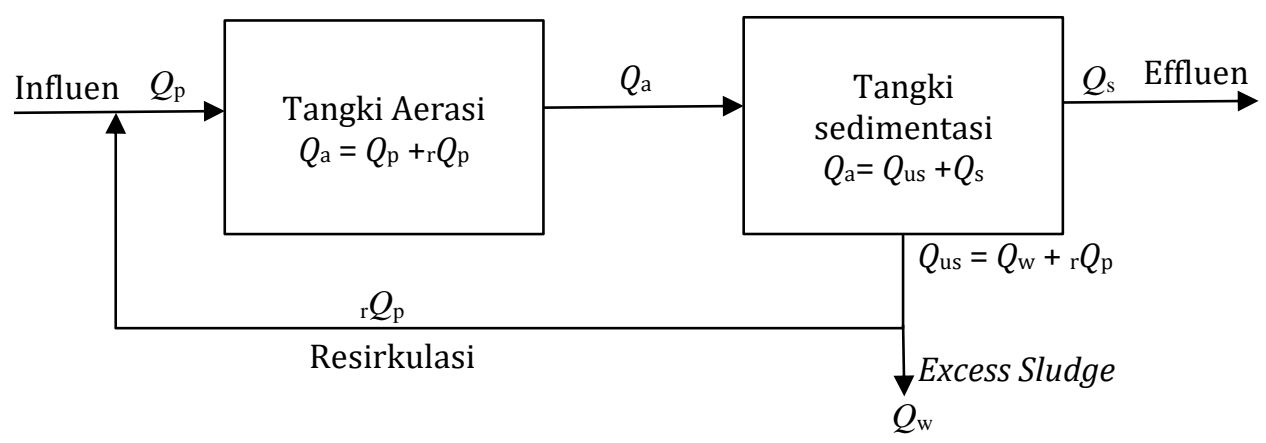

Gambar 1 Konfigurasi dan skema kesetimbangan debit 
Tabel 2. Ketentuan nilai $C_{d}$

Bilangan Reynolds

$C_{d}$ (Drag Coefficient)

\begin{tabular}{cc}
\hline 1 $>$ Bilangan Reynolds & $C_{\mathrm{d}}=\frac{24}{R}=\frac{24 \mu}{v \rho d}$ \\
$1<$ Bilangan Reynolds $<1000$ & $C_{\mathrm{d}}=\frac{24}{R}+\frac{3}{R^{0,5}}+0.34=\frac{18,5}{R^{0,5}}$ \\
Bilangan Reynolds $>1000$ & $C_{\mathrm{d}}=0,34$ atau 0,40 \\
$1>$ Bilangan Reynolds & $C_{\mathrm{d}}=\frac{24}{R}=\frac{24 \mu}{v \rho d}$ \\
$1<$ Bilangan Reynolds $<1000$ & $C_{\mathrm{d}}=\frac{24}{R}+\frac{3}{R^{0,5}}+0.34=\frac{18,5}{R^{0,5}}$ \\
\hline
\end{tabular}

Sumber: (Lee dan Lin, 2007)

\section{Hasil dan Pembahasan}

\subsection{Karakteristik limbah cair industri kertas}

Karakteristik limbah cair industri kertas ditinjau dari konsentrasi COD dan TS limbah cair industri kertas di efluen unit aerasi, efluen unit aerasi, dan efluen unit sedimentasi. Berdasarkan Gambar 1, konsentrasi COD RAW limbah cair industri kertas berkisar 176-474 $\mathrm{mg} / \mathrm{L} \quad \mathrm{O}_{2}$ dengan rata-rata konsentrasi COD sebesar $346 \mathrm{mg} / \mathrm{L} \mathrm{O}$. Setelah melewati proses pengolahan biologis, konsentrasi COD mengalami penurunan dengan konsentrasi di efluen unit aerasi mencapai 18 - $223 \mathrm{mg} / \mathrm{L} \mathrm{O}_{2}$ dengan ratarata konsentrasi COD sebesar $124 \mathrm{mg} / \mathrm{L} \mathrm{O}_{2}$. Proses pengendapan partikel di unit sedimentasi memberi sebagian kontribusi terhadap penurunan COD dengan kisaran konsentrasi COD sebesar 37 - $252 \mathrm{mg} / \mathrm{L} \mathrm{O}_{2}$ dengan rata-rata konsentrasi COD efluen sedimentasi sebesar $117 \mathrm{mg} / \mathrm{L} \mathrm{O}_{2}$. Interaksi partikel yang terjadi di dalam unit sedimentasi memengaruhi penurunan konsentrasi COD. Umumnya, suatu partikel di dalam media air membawa muatan listrik yang sering disebut zeta potential. Menurut Verma et al. (2011), pembentukan flok dengan densitas yang lebih besar dari densitas cairan direpresentasikan dengan tingginya nilai zeta potential. Nilai zeta potential tinggi juga memberikan dampak terhadap peningkatan efisiensi reduksi COD. Berdasarkan hasil penelitian pada Gambar 1 dan pernyataan Verma et al. (2011), partikel dalam limbah cair industri kertas memiliki kecenderungan yang tinggi untuk membentuk flok dan berperan aktif dalam peningkatan efisiensi reduksi COD dan TS pada pengolahan limbah industri kertas dengan konfigurasi lumpur aktif.

Gambar 2 menunjukkan peningkatan efisiensi reduksi COD seiring dengan penambahan HRT. Efisiensi reduksi COD pada HRT 6 jam, 8 jam, dan 12 jam berturut-turut mencapai 56,64\%; 64,92\%,; dan 70,80\%. Meskipun demikian, nilai efisiensi reduksi COD pada penelitian ini masih belum mencapai efisiensi yang diharapkan karena pengolahan biologis seharusnya bisa mereduksi kadar COD di dalam limbah cair hingga 95\% (Zho u et al., 2018). Kondisi ini dapat diakibatkan oleh mikroorganisme filamen berlebih di dalam air limbah yang menyebabkan pemisahan padatan menjadi lebih sulit (bulking sludge) sehingga kemampuan pengendapan dan pemadatan bioflok menurun (Amanatidou et al,. 2015). Bulking sludge muncul ketika umur lumpur (Solid Retention Time/SRT) tinggi dan diiringi dengan peningkatan konsentrasi nitrat akibat pelepasan gas denitrifikasi sehingga menurunkan densitas flok. Walaupun peningkatan HRT hingga 12 jam memberikan peningkatan efisiensi COD sebesar 70,80\% dan menyediakan volume reaktor yang cukup besar, peningkatan biomassa akan memberikan implikasi terhadap risiko bulking sludge terjadi pada SRT yang tinggi. Beberapa alternatif untuk mengkaji fenomena ini dapat menguji pengaruh SRT di dalam kinerja unit, dan menganalisis parameter biokinetika mikrooganisme yang dipengaruhi oleh inhibitor. Parameter biokinetika mikroorganisme seperti laju pertumbuhan spesifik, faktor kematian mikroorganisme, laju pertumbuhan maksimum, dan konsentrasi saturasi (Curtin et al., 2011). Parameter biokinetika dalam proses pengolahan biologis berhubungan erat dengan jumlah biomassa dalam unit aerasi. Jumlah biomassa sering kali direpresentasikan dengan jumlah MLSS dalam unit aerasi. Parameter pengujian yang menunjukkan besar MLSS dalam reaktor lumpur aktif, yaitu padatan total (TS).

Gambar 3 menunjukkan konsentrasi TS di unit aerasi lebih besar dibandingkan konsentrasi TS influen unit aerasi dan efluen di unit sedimentasi. Konsentrasi TS influen berkisar antara 220-1.200 mg/L. Konsentrasi TS limbah cair meningkat saat mengalami proses biologis dalam unit aerasi hingga mencapai 540-5.728 mg/L. Peningkatan konsentrasi TS menunjukkan peningkatan jumlah biomassa dalam unit aerasi (Harms et al., 2003). Sementara itu, konsentrasi TS efluen sedimentasi mengalami penurunan dengan kisaran 103-517 mg/L. Pengaruh proses pengendapan terhadap efisiensi reduksi TS dikaji melalui analisis discrete particle settling dan flocculant settling. 
COD influen aerasi m COD aerasi ^ COD sedimentasi

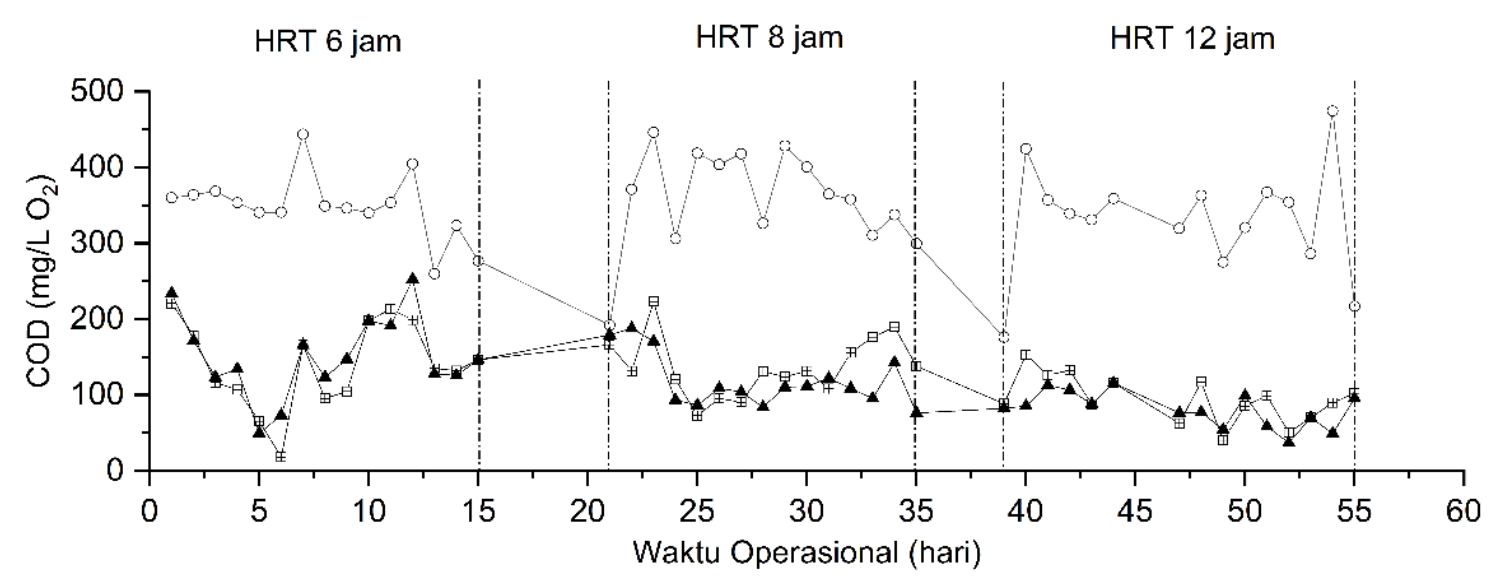

Gambar 2 Rekapitulasi konsentrasi COD limbah cair industri kertas

${ }_{-}-$TS influen aerasi-_ TS aerasi $\_$- TS sedimentasi

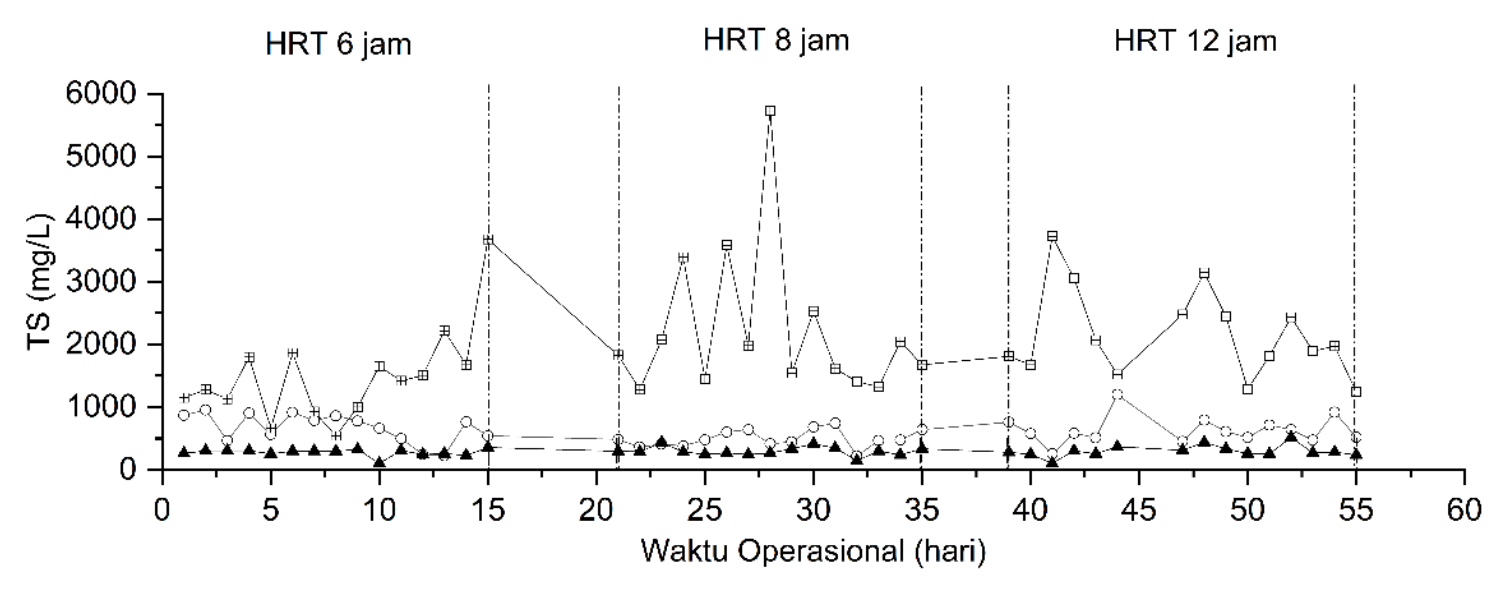

Gambar 3 Rekapitulasi konsentrasi TS limbah cair industri kertas

\subsection{Pengendapan diskrit (discrete particle settling)}

Pengamatan terhadap discrete particle settling diperoleh data kecepatan pengendapan dan estimasi diameter partikel limbah cair industri kertas. Berdasarkan Gambar 4, tren kecepatan pengendapan untuk partikel diskrit diketahui mengikuti tren diameter partikel dan bilangan Reynolds. Ketika diameter partikel dalam limbah cair pada Gambar 4 (b) mengalami peningkatan dari 0,033 $\mathrm{mm}$ ke 0,041 $\mathrm{mm}$, maka nilai kecepatan pengendapan partikel juga meningkat dari 0,0011 m/detik ke 0,00167 m/detik serta bilangan Reynolds meningkat dari 0,04 ke 0,076. Pengaruh diameter partikel terhadap kecepatan dapat diketahui melalui nilai drag coefficient $\left(C_{d}\right)$. Semakin kecil ukuran partikel dalam limbah cair, maka luas permukaan dinding partikel akan meningkat. Penambahan luas permukaan dinding partikel akan meningkatkan gaya hambat atau $C_{d}$ dan menurunkan kecepatan pengendapan partikel (Kishore dan Gu, 2010). Selain itu, semakin tinggi nilai $C_{d}$, maka nilai bilangan Reynolds akan semakin rendah sesuai dengan ketentuan pada Tabel 2 (Lee dan Lin, 2007).

Gambar 4 (a) menunjukkan bahwa kisaran kecepatan pengendapan diskrit pada operasional HRT lumpur aktif 6 jam berada antara 0,0018-0,0021 $\mathrm{m} /$ detik. Kisaran kecepatan pengendapan diskrit pada operasional HRT lumpur aktif 8 jam lebih kecil dibandingkan kecepatan diskrit pada operasional HRT 6 jam dengan nilai antara 0,0011-0,0019 m/detik seperti pada Gambar (b). Selain itu, kecepatan pengendapan pada operasional HRT lumpur aktif 12 jam (Gambar 4 (c)) memiliki kecepatan pengendapan diskrit dengan rentang nilai 0,0017-0,0019 m/detik.

Besarnya ukuran partikel memengaruhi energi potensial partikel ketika jatuh bebas mengikuti arah percepatan gravitasi (Wu dan Bevan, 2005). Semakin 
besar ukuran partikel dalam limbah cair industri kertas, maka kecepatan partikel untuk mengendap akan semakin besar. Pernyataan tersebut didukung oleh hasil penelitian pada Gambar 4 (a) bahwa partikel dengan diameter $0,042 \mathrm{~mm}$ memiliki kecepatan pengendapan diskrit sebesar 0,00181 m/detik, partikel dengan diameter $0,043 \mathrm{~mm}$ memiliki kecepatan pengendapan diskrit sebesar 0,00187 $\mathrm{m} /$ detik, sedangkan partikel dengan diameter 0,044 $\mathrm{mm}$ memiliki kecepatan pengendapan sebesar 0,00194 $\mathrm{m} /$ detik. Besar diameter dalam fenomena ini tidak hanya merepresentasikan ukuran entitas partikel, tetapi ukuran flok dalam limbah cair. Hal itu terjadi karena setiap entitas partikel memiliki nilai zeta potential yang berbeda. Semakin rendah nilai zeta potential suatu partikel maka gaya tolak elektrostatik yang dimilikinya semakin rendah (Novoa et al., 2020). Umumnya, partikel dengan diameter kecil memiliki tolakan elektrostatik yang rendah dan memiliki kecenderungan yang lebih tinggi untuk mengalami adhesi. Jika ditinjau dari perubahan HRT pada operasional lumpur aktif, maka rata-rata diameter partikel terbesar terkandung pada sampel dengan operasional HRT 6 jam sebesar 0,44 mm, sedangkan diameter partikel untuk HRT 8 jam dan HRT 12 jam hanya sebesar $0,40 \mathrm{~mm}$, dan $0,42 \mathrm{~mm}$. Nilai tertinggi dari variasi HRT yang dioperasikan berada pada HRT 6 jam. Akan tetapi, HRT yang kecil justru memicu sebaran distribusi partikel yang tidak stabil dan memiliki zeta potential yang rendah (Novoa et al., 2020). Fakta tersebut menunjukkan bahwa pada HRT 6 jam, ukuran diameter untuk setiap entitas partikel sebenarnya memiliki ukuran yang kecil, tetapi dengan pengaruh interaksi akibat zeta potensial dan stabilitas partikelnya membuat partikel pada sampel HRT 6 jam lebih mudah untuk membentuk flok dan memiliki kecepatan pengendapan yang lebih tinggi dibandingkan HRT operasional lainnya.

\subsection{Pengendapan flok (flocculant settling)}

Pengamatan terhadap flocculant settling diperoleh data persentase reduksi padatan total pada kedalaman dan durasi pengendapan tertentu. Pengamatan ini ditujukan untuk pembuatan kurva isokonsentrasi sebagai media untuk menghitung total reduksi padatal total. Kurva isokonsentrasi menunjukkan persentase jalur pengendapan maksimum terhadap persentase reduksi TS (Jargensen, 1979). Sebagai contoh, kurva isokonsentrasi Gambar 5 (a) ditunjukkan oleh jalur persentase reduksi sebesar $83,13 \%$ dan $85,00 \%$.

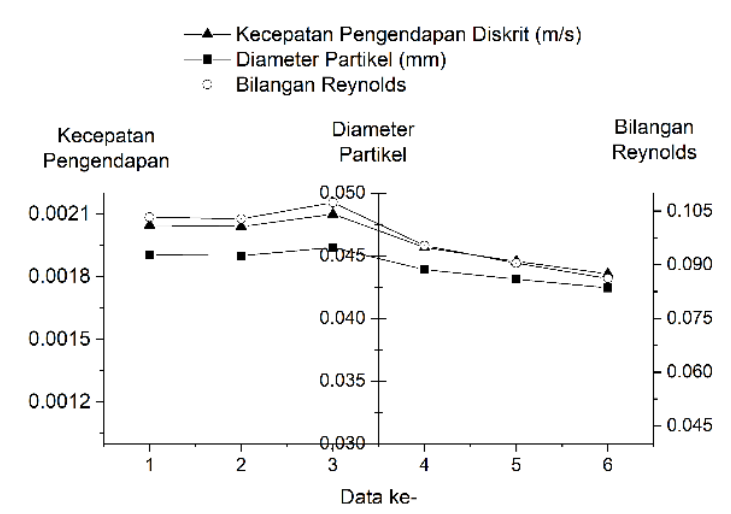

(a)

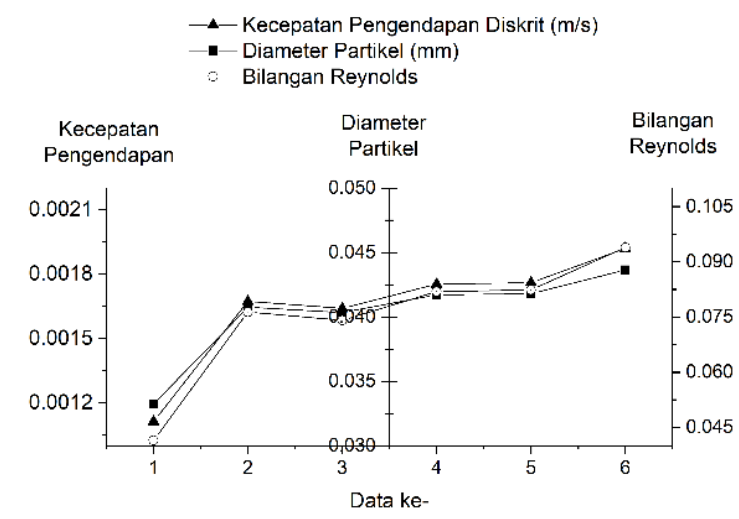

(b)

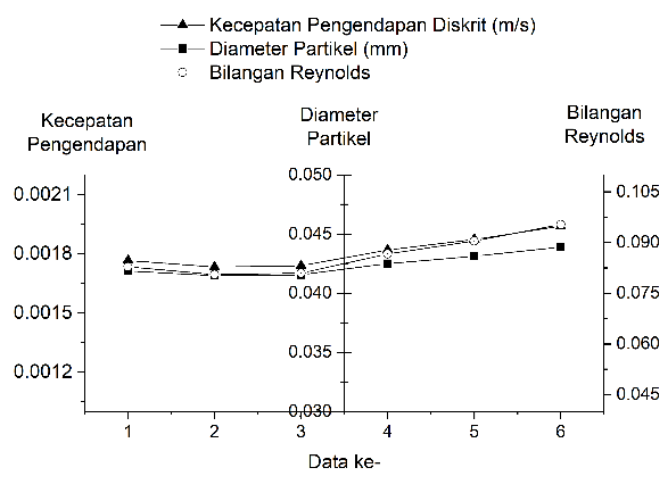

(c)

Gambar 4 Perbandingan kecepatan pengendapan diskrit, diameter partikel, dan bilangan Reynold. (a) HRT 6 jam; (b) HRT 8 jam; (c) HRT 12 jam 
Kurva tersebut menunjukkan posisi kedalaman dan kebutuhan durasi pengendapan untuk memperoleh persentase reduksi padatan total sebesar $83,13 \%$ dan 85,00\%. Gambar 5-7 menggambarkan hasil pengujian reduksi padatan total yang disertai dengan kurva isokonsentrasi dalam bentuk garis dan kontur warna. Gambar 5 terdiri atas tiga kurva isokonsentrasi terbaik dari enam sampel unit sedimentasi HRT 6 jam. Ketiga kurva tersebut menghasilkan tren data yang berbeda meskipun secara garis besar memiliki satu kemiripan, yaitu karakteristik reduksi partikel akibat perubahan durasi pengendapan. Gambar 5 menunjukkan bahwa semakin besar durasi pengendapan, maka persentase reduksi padatan akan meningkat. Misalnya Gambar 5 (b), persentase reduksi padatan pada kedalaman uji 15 cm menit ke-15, 30, 45, dan 75 berturut-turut sebesar 88,40\%; 91,11\%; 91,60\%; 92,84\%; dan 93,58\%. Selisih persentase reduksi untuk setiap menit cenderung acak dan berfluktuasi. Antara menit ke-15 dan ke-30, perbedaan persentase reduksi sebesar 2,71\%, sedangkan antara menit ke-30 dan ke-45, perbedaan persentase reduksi hanya sebesar $0,49 \%$. Fenomena ini bisa saja dipengaruhi oleh perubahan kecepatan pengendapan partikel limbah cair. Ada kecenderungan partikel membentuk flok antara menit ke-15 dan 30 . Pembentukan flok pada rentang waktu tersebut dapat memicu bertambahnya kecepatan pengendapan akibat meningkatnya energi potensial flok (Wu dan Bevan, 2005). Akan tetapi, antara menit 30 dan 45 peningkatan kecepatan pengendapan tidak terjadi sehingga penurunan konsentrasi reduksi TS berkurang. Hal ini disebabkan ukuran flok yang terbentuk pada menit sebelumnya membuat diameter partikel membesar dan meningkatkan gaya tolak elektrostatik antar partikel (Novoa et al., 2020).

Berdasarkan Gambar 5, Gambar 6, Gambar 7 sebagian besar persentase reduksi padatan memiliki nilai yang acak untuk setiap variasi titik kedalaman dan durasi pengendapan. Misalnya, pada Gambar 6(a), beberapa spot warna hijau tersebar pada durasi pengendapan 30 menit dan 65 menit. Warna hijau pada Gambar 6 (c) menunjukkan nilai persentase reduksi padatan total antara 81,96 hingga 85,74\%. Idealnya, semakin lama durasi pengendapan yang diterapkan dalam unit sedimentasi maka persentasi reduksi akan semakin besar (Saleh et al,. 2015). Namun, Gambar 6(c), nilai persentasi reduksi padatan total berfluktuasi terhadap perubahan durasi pengendapan.

Fenomena yang terjadi pada proses pengendapan lumpur aktif berkaitan erat dengan efek magnetik nanopartikel. Interaksi elektrostatik antara kationik nanopartikel dan anionik sel mikroorganisme memungkinkan lumpur mengalami proses agregasi dan membentuk flok secara alami (Chhuon et al., 2020). Akan tetapi, proses agregasi alami sulit untuk dikontrol karena muatan yang terkandung pada permukaan partikel tidak dapat dinetralkan (interaksi kationik dan anionik) sehingga dibutuhkan bantuan zat aditif untuk menjembatani pembentukan flok (Chen et al., 2016). Nilai persentase reduksi padatan total yang acak menunjukkan bahwa lumpur limbah industri kertas di unit sedimentasi lumpur aktif kurang mampu membentuk flok secara alami dan cenderung mengendap berdasarkan karakteristik entitas partikel. Oleh karena itu, untuk meningkatkan potensi pembentukan flok dan membuat persentase reduksi padatan total semakin tinggi, penambahan zat aditif dibutuhkan berupa flokulan atau koagulan.

Apabila persentase reduksi padatan total ditinjau secara keseluruhan berdasarkan perubahan waktu detensi operasional lumpur aktif (HRT 6 jam, 8 jam, dan 12 jam), maka peristiwa flocculant settling menunjukkan kecenderungan peningkatan reduksi padatan berdasarkan peningkatan durasi pengendapan. Hal ini diperkuat oleh hasil pengamatan pada sampel HRT 6 jam (Gambar 5) dan HRT 12 jam (Gambar 7). Misalnya, pada Gambar 7(c), nilai persentase reduksi padatan total pada menit ke-15, 30, 45, 60, dan 75 di titik kedalaman $15 \mathrm{~cm}$ berturut-turut sebesar 82,22\%; 83,11\%; 85,33\%; 85,33\%; dan $86,67 \%$. Peningkatan reduksi padatan total akibat peningkatan durasi pengendapan disebabkan oleh perilaku pengendapan untuk partikel tersuspensi atau flok yang semakin lama semakin terakumulasi ke dasar unit sedimentasi (Mohammed dan Shakir, 2018). Jika nilai persentasi reduksi di setiap kedalaman diakumulasi, maka total reduksi di kedalaman 15,48 cm dan durasi pengendapan 45 menit untuk HRT 6 jam, 8 jam, dan 12 jam berturut-turut sebesar 91,04\%; 90,90\%; dan 91,87\% dengan HLR sebesar 4,9 $\mathrm{m}^{3} / \mathrm{m}^{2}$.hari.

\subsection{Estimasi Hydraulic Loading Rate dan Solid Loading Rate}

Berdasarkan pembahasan sebelumnya, hasil penelitian terkait discrete particle settling menyatakan partikel dalam limbah cair industri kertas memiliki kecenderungan membentuk flok secara alami dan meningkatkan kecepatan pengendapan. Penelitian tersebut dilanjutkan dengan pengamatan flocculant settling yang membuktikan bahwa flok di dalam limbah cair tanpa adanya zat aditif (flokulan atau koagulan) tidak dapat memberikan kinerja reduksi padatan total yang maksimal dan kontinu berdasarkan perubahan durasi pengendapan. Selain itu, penentuan kriteria desain unit sedimentasi untuk limbah cair industri kertas ditinjau dari karakteristik mayoritas pengendapan partikel dan diperoleh nilai SLR dan HLR untuk setiap variasi waktu detensi operasional lumpur aktif. Apabila ditinjau dari nilai SLR dan HLR konvensional menurut Qasim dan Zhu (2017), nilai SLR dan HLR dari penelitian ini dapat digunakan dalam perencanaan unit skala lapangan karena masih berada di dalam rentang kriteria desain yang umum digunakan Tabel 3. 

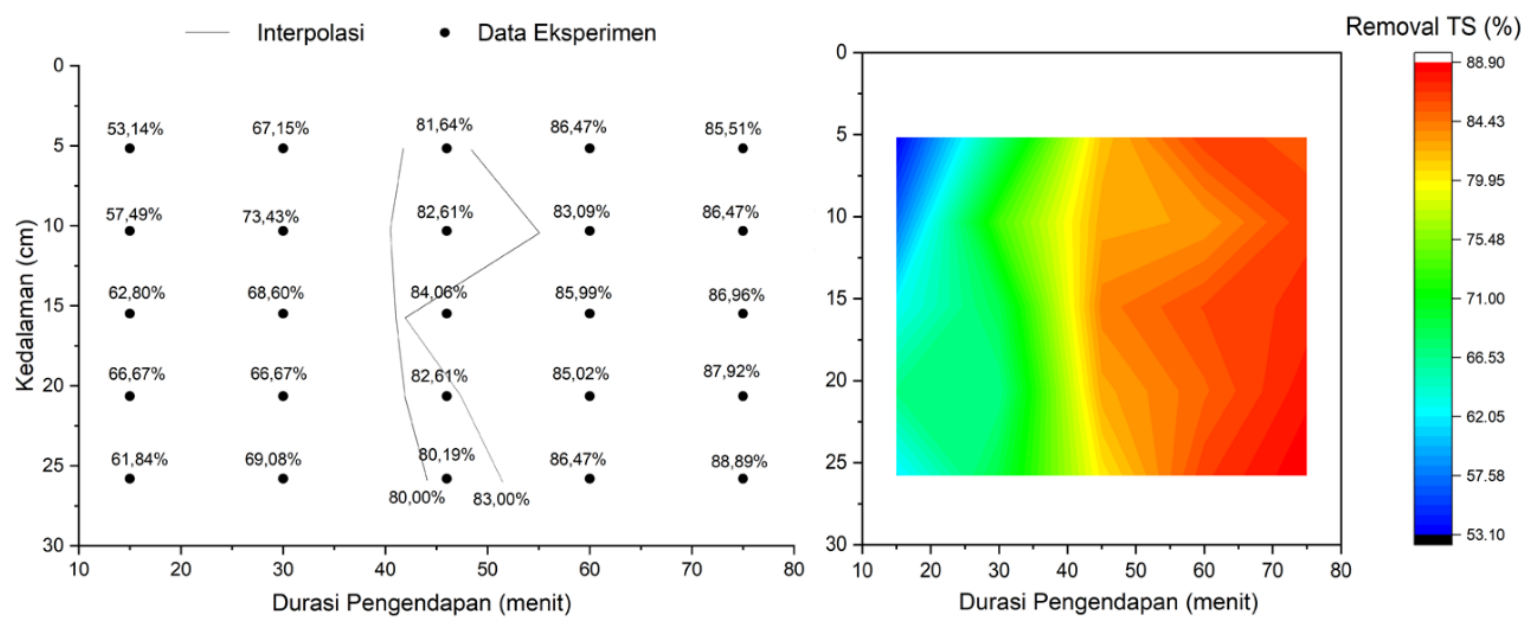

(a)
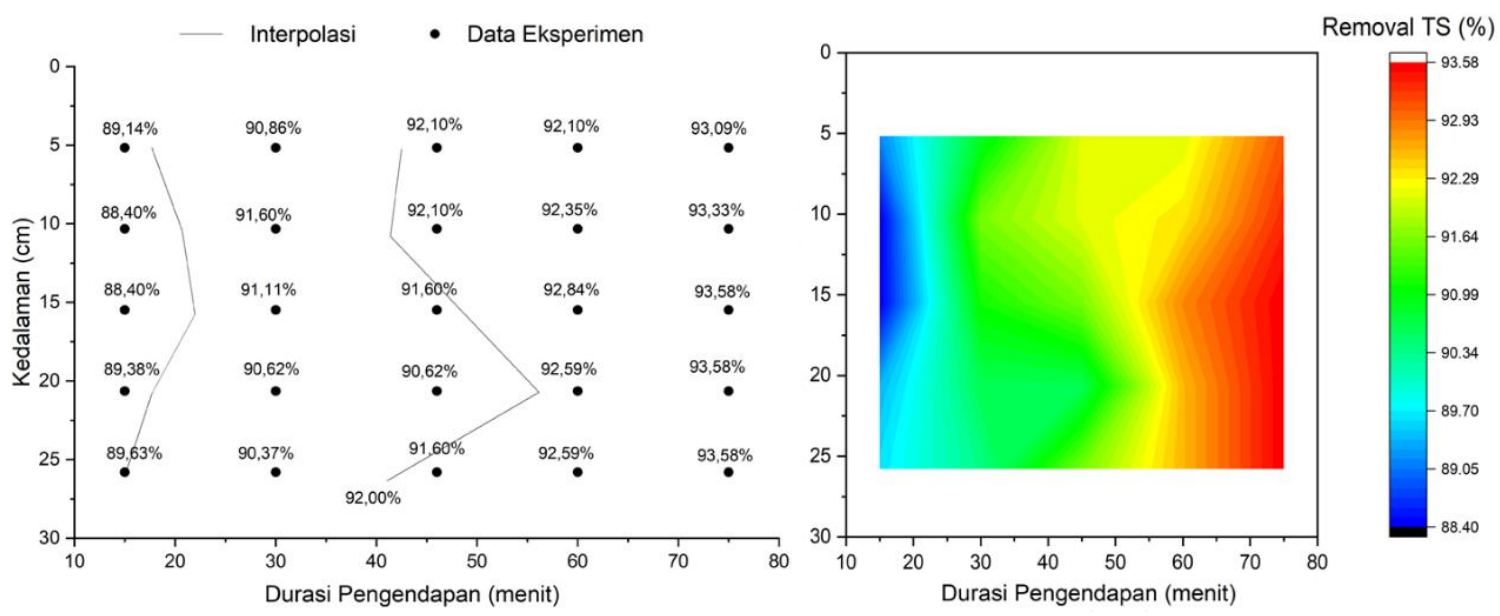

(b)
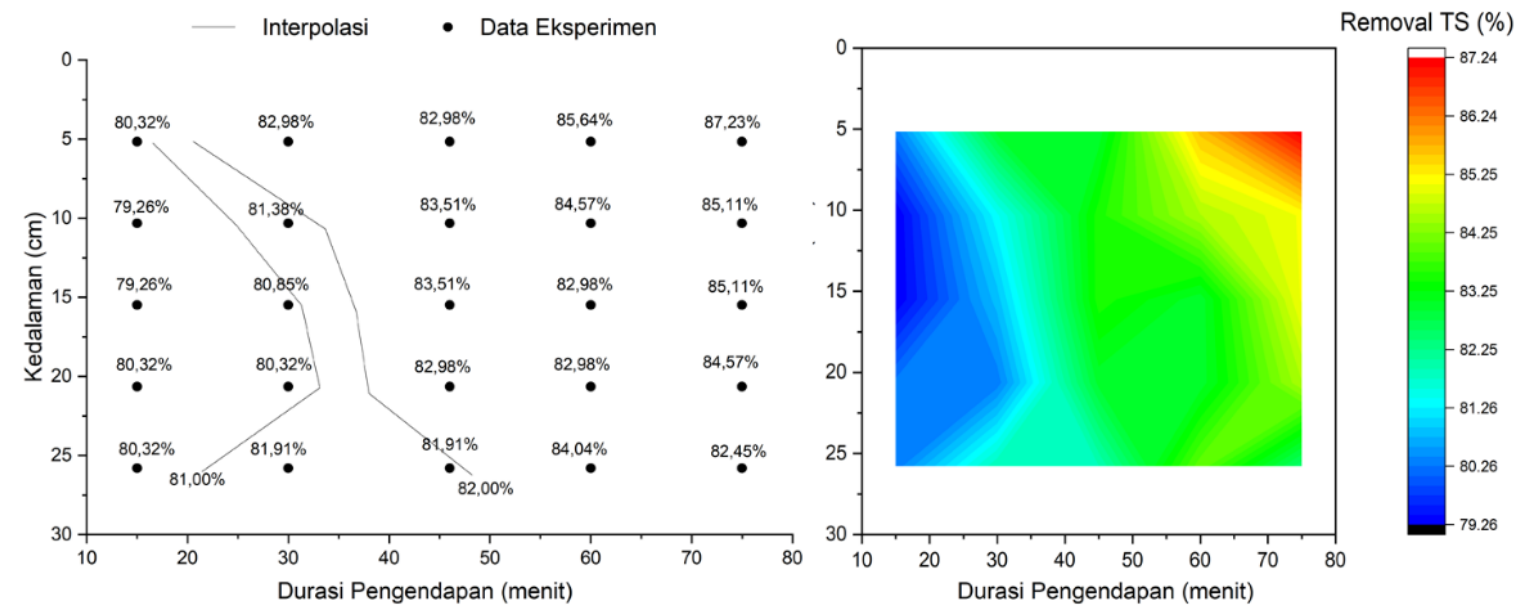

(c)

Gambar 5 Data persen reduksi flocculant settling HRT 6 jam 

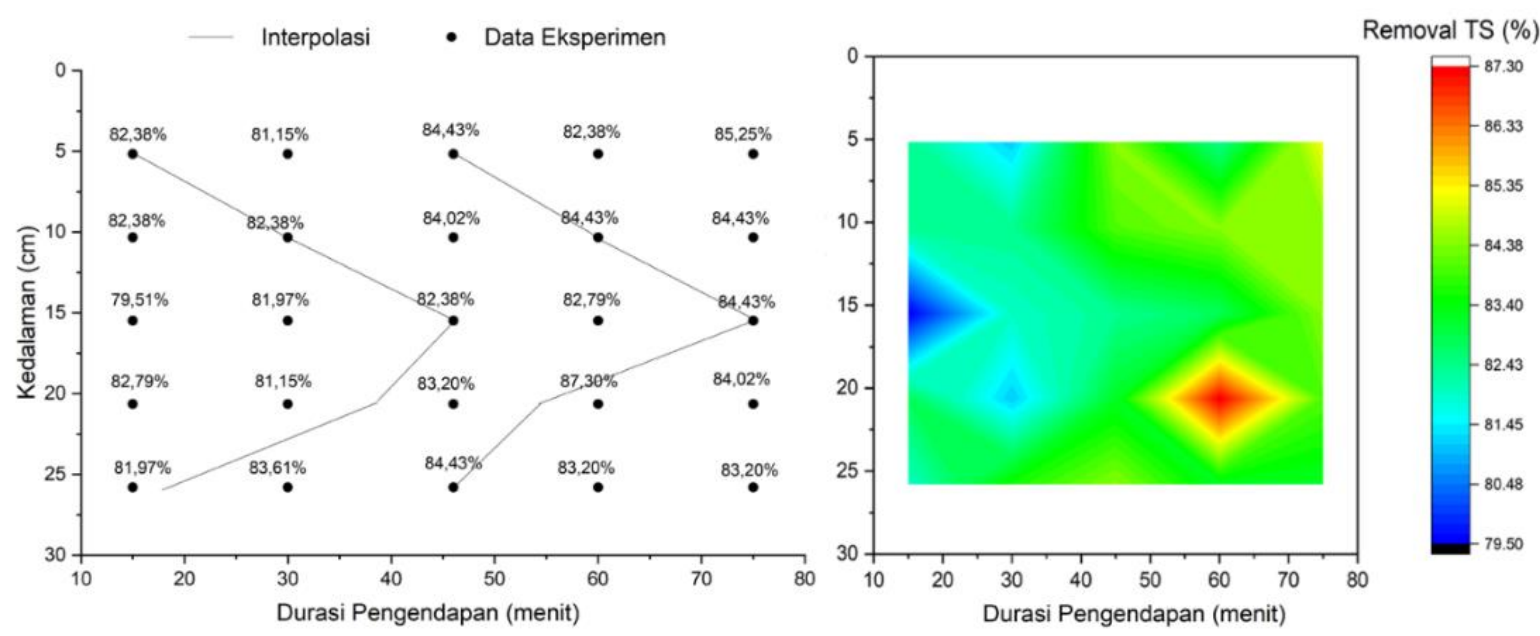

(a)
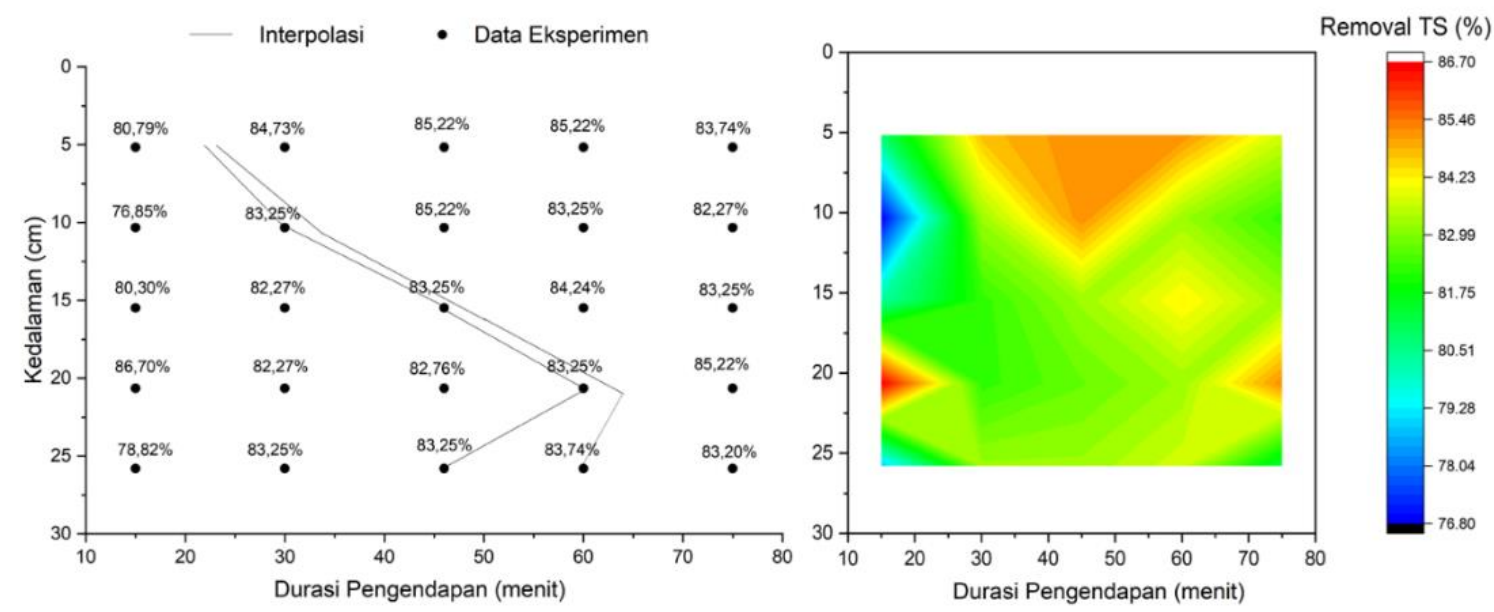

(b)
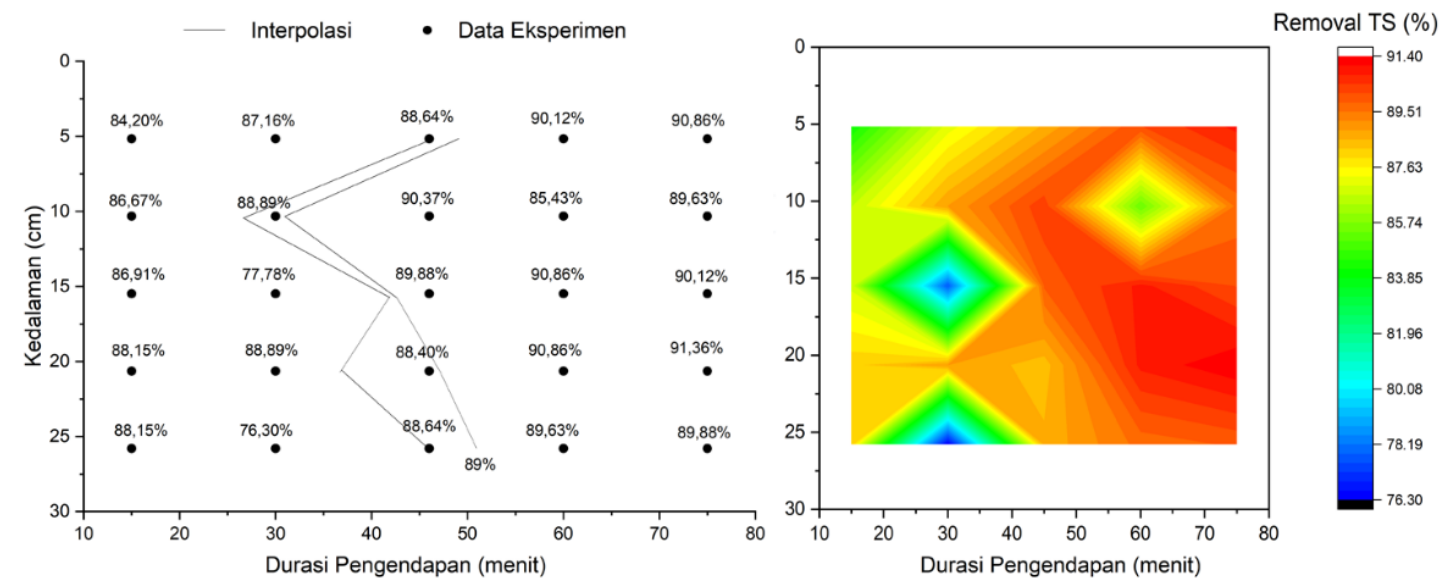

(c)

Gambar 6 Data persen reduksi flocculant settling HRT 8 jam 

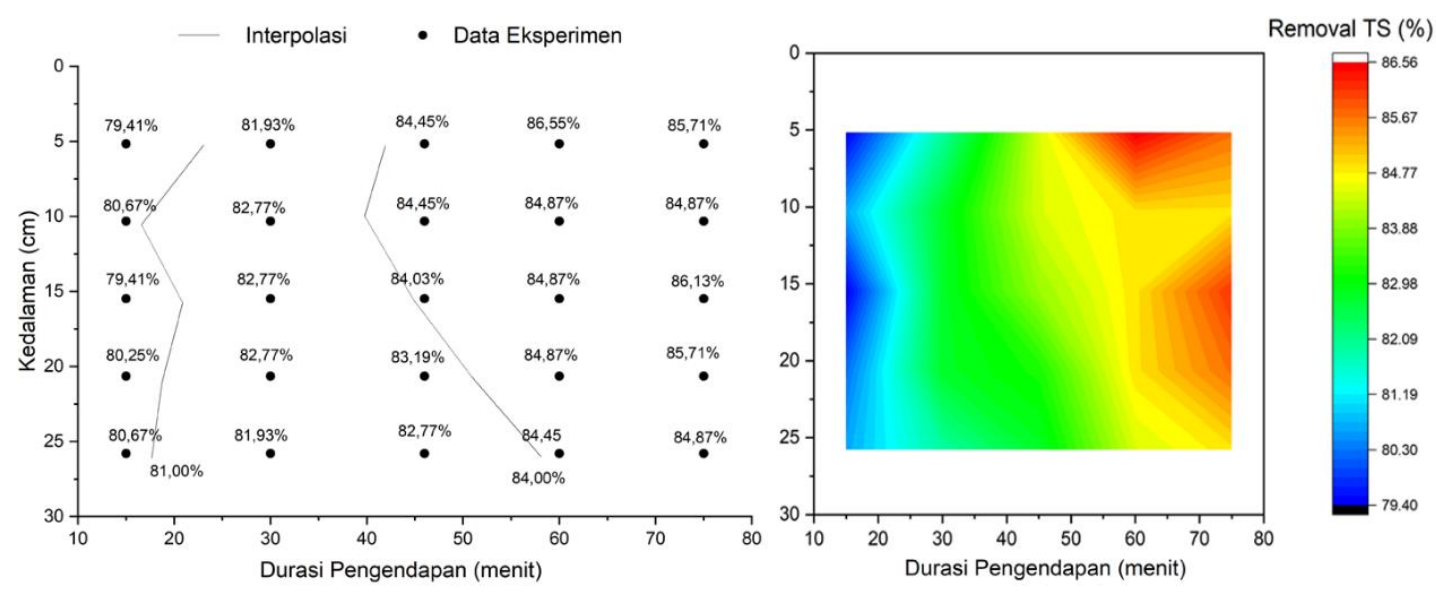

(a)
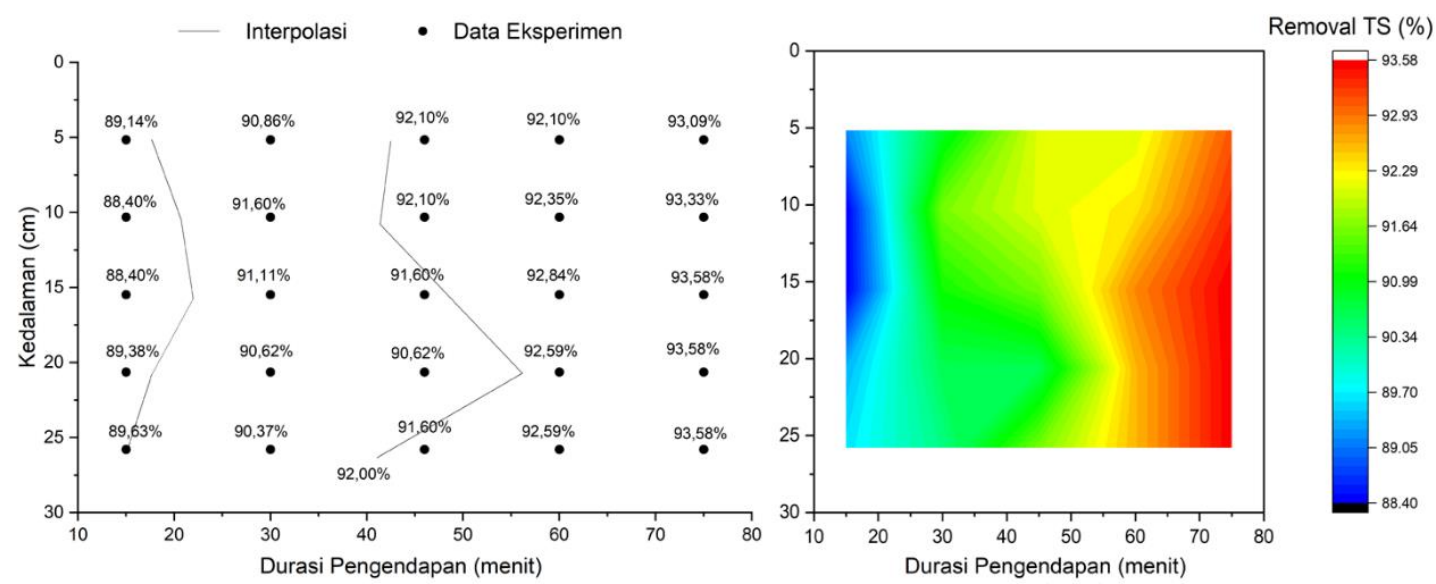

(b)
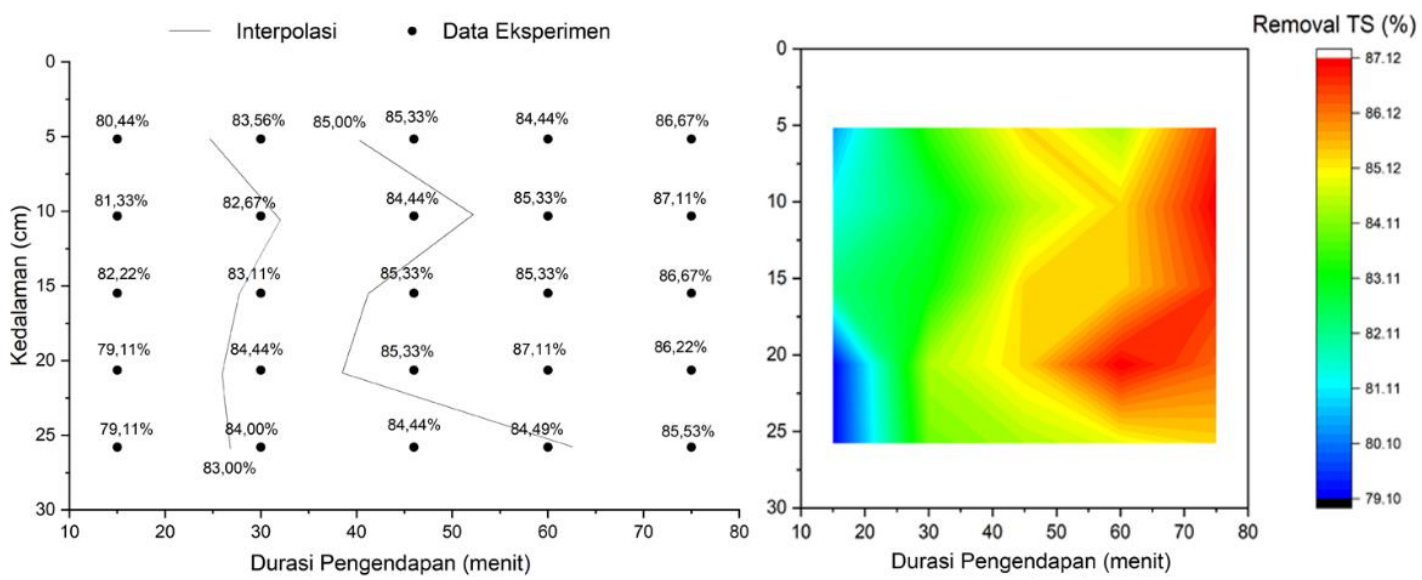

(c)

Gambar 7 Data persen reduksi flocculant settling HRT 12 jam

Apabila meninjau produksi kertas pada tahun 2000, jumlah kertas yang diproduksi pada masa itu sebanyak 6.849.000 ton (Wulandari, 2007). Selain itu, jumlah produksi limbah cair untuk 1 ton kertas mencapai 60 $\mathrm{m}^{3}$ (Klidi et al. 2019). Berdasarkan data tersebut, estimasi limbah cair industri kertas bisa mencapai
410.940.000 $\mathrm{m}^{3} /$ tahun atau $1.125 .863 \mathrm{~m}^{3} /$ hari. Menurut Balai Besar Pulp dan Kertas dari Kementerian Perindustrian (2021), jumlah industri kertas mencapai 84 perusahaan. Oleh karena itu, estimasi produksi limbah cair untuk setiap perusahaan bisa mencapai $13.500 \mathrm{~m}^{3} /$ hari. Jika diasumsikan sebuah pabrik 
memproduksi limbah cair hingga $1000 \mathrm{~m}^{3} /$ hari, maka luas area yang dibutuhkan untuk mengolah limbah cair tersebut semakin besar seiring bertambahnya debit influen limbah cair. Estimasi dimensi dilakukan dengan data HLR yang disesuaikan dengan konsentrasi padatan limbah cair pada Tabel 4 dan Tabel 5 serta rasio panjang dan lebar unit sebesar 1,5:1 (Qasim dan Zhu, 2017). Sesuai dengan definisi HLR yang menyatakan jumlah limbah dapat diolah dalam satuan luas tertentu (Samal dan Dash 2021), semakin tinggi nilai HLR maka kebutuhan luas area untuk pengendapan akan semakin besar. Misalnya, pada HRT 6 jam dengan HLR sebesar $42,16 \mathrm{~m}^{3} / \mathrm{m}^{2}$ hari dan debit $100 \mathrm{~m}^{3} /$ hari, kebutuhan dimensi sebesar $2,37 \mathrm{~m}^{2}$. Selain itu, pada HRT 12 jam dengan HLR 21,08 $\mathrm{m}^{3} / \mathrm{m}^{2}$ hari dan debit $100 \mathrm{~m}^{3} /$ hari, kebutuhan dimensi luas unit sebesar $4,74 \mathrm{~m}^{2}$.

Estimasi SLR dilakukan setelah dimensi unit (luas, panjang, dan lebar unit), HRT, dan HLR ditentukan. Berdasarkan asumsi konsentrasi TS influen sedimentasi untuk setiap sampel HRT mengikuti data pada Tabel 3, maka SLR pada HRT 6 jam, 8 jam, dan 12 jam, yaitu 102,46 kg/m²hari, 70,14 $\mathrm{kg} / \mathrm{m}^{2}$ hari, $134,50 \mathrm{~kg} / \mathrm{m}^{2}$ hari. Jika ditinjau dari nilai SLR, HRT 8 jam menunjukkan kondisi under loaded pada unit sedimentasi. Apabila waktu operasional HRT 8 jam diterapkan dalam skala lapangan, maka kerugian secara finansial dapat terjadi. Sementara itu, HRT 6 jam dan HRT 12 jam memiliki nilai HLR dan SLR yang memenuhi rentang kriteria desain lumpur aktif menurut Qasim dan Zhu (2017). Dengan demikian, desain terbaik untuk unit sedimentasi sekunder lumpur aktif, yaitu HRT 6 jam dengan HLR sebesar $42,16 \mathrm{~m}^{3} / \mathrm{m}^{2}$ hari, SLR sebesar $102,45 \mathrm{~kg} / \mathrm{m}^{2}$ hari dan rata-rata reduksi padatan total mencapai $89,26 \%$ (Gambar 5). Selain itu, HRT 6 jam merepresentasikan waktu tinggal air limbah di dalam unit pengolahan lebih kecil dibandingkan HRT 12 jam, sehingga volume unit yang dibutuhkan pada perencanaan dengan HRT 6 jam tidak sebesar perencanaan dengan HRT 12 jam.

Tabel 3. Estimasi nilai solid loading rate (SLR) dan Hydraulic loading rate (HLR)

\begin{tabular}{|c|c|c|c|c|c|}
\hline \multirow{2}{*}{$\begin{array}{l}\text { Variasi HRT } \\
\text { (Jam) }\end{array}$} & \multicolumn{2}{|c|}{ Hasil penelitian } & \multicolumn{2}{|c|}{ Qasim dan Zhu (2017) } & \multirow{2}{*}{ Keterangan } \\
\hline & $\operatorname{SLR}\left(\mathrm{kg} / \mathrm{m}^{2}\right.$ hari) & $\operatorname{HLR}\left(\mathrm{m}^{3} / \mathrm{m}^{2}\right.$ hari $)$ & $\operatorname{SLR}\left(\mathrm{kg} / \mathrm{m}^{2}\right.$ hari $)$ & $\operatorname{HLR}\left(\mathrm{m}^{3} / \mathrm{m}^{2} \mathrm{hari}\right)$ & \\
\hline $\begin{array}{c}6 \\
8 \\
12\end{array}$ & $\begin{array}{c}102,46 \\
70,14 \\
134,50\end{array}$ & $\begin{array}{l}42,16 \\
31,62 \\
2108\end{array}$ & $\begin{array}{c}96-144^{*} \\
192-240^{* *}\end{array}$ & $\begin{array}{c}16-24^{*} \\
40-48^{* *}\end{array}$ & $\begin{array}{l}\text { Memenuhi } \\
\text { SLR terlalu rendah }\end{array}$ \\
\hline
\end{tabular}

*Untuk debit rata

**Untuk debit puncak

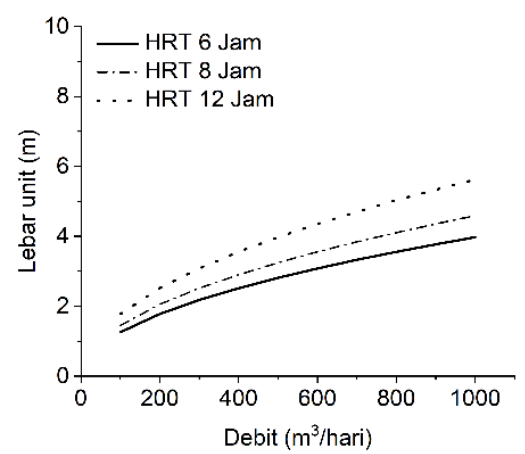

(a)

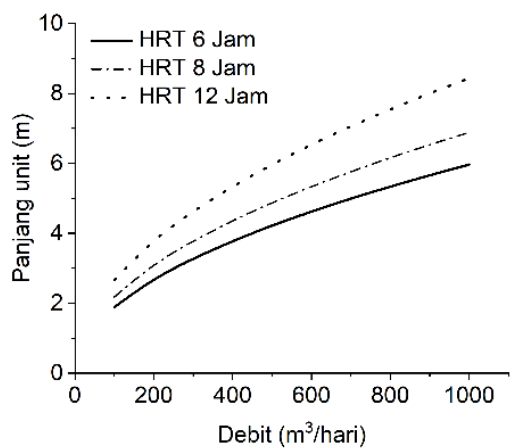

(b)

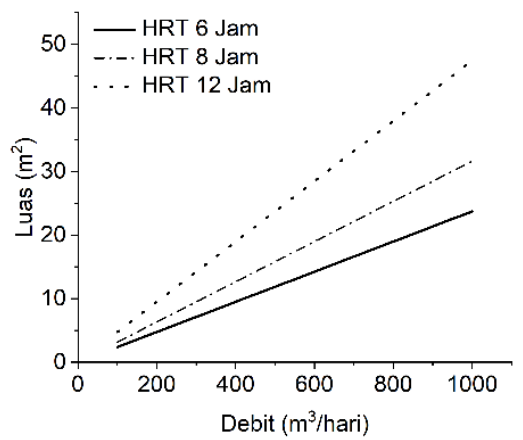

(c)

Gambar 8 Penentuan dimensi unit sedimentasi berdasarkan nilai HLR di setiap variasi HRT lumpur aktif. (a) Prediksi lebar unit; (b) Prediksi panjang unit; (c) Prediksi luas unit 


\section{Kesimpulan}

Berdasarkan hasil dan pembahasan, penelitian ini disimpulkan bahwa kecepatan pengendapan discrete particle settling tergantung pada karakteristik satuan partikel yang dilihat dari diameter partikel. Kecepatan pengendapan flocculant settling tergantung pada pengaruh interaksi partikel dalam pembentukan flok atau gumpalan beberapa entitas partikel. Reduksi padatan total dengan konfigurasi lumpur aktif dapat mencapai 89,26\%. Rekomendasi kriteria desain untuk memperoleh efisiensi reduksi TS terbaik dengan biaya yang rendah dalam pengolahan limbah cair industri kertas dengan lumpur aktif, yaitu dengan menerapkan HRT lumpur aktif selama 6 jam dengan HLR sebesar $42,16 \mathrm{~m}^{3} / \mathrm{m}^{2}$ hari, dan SLR sebesar 102,45 kg/m²hari.

\section{DAFTAR PUSTAKA}

Amanatidou E, Samiotis G, Trikoilidou E, Pekridis G, Taousanidis N. 2015. Evaluating sedimentation problems in activated sludge treatment plants operating at complete sludge retention time. Water Res..doi:10.1016/j.watres.2014.10.061.

Assadi A, Alimoradzadeh R, Movahedyan H, Amin MM. 2020. Intensified 4-chlorophenol biodegradation in an aerobic sequencing batch reactor: Microbial and kinetic properties evaluation. Environ. Technol. Innov.doi:10.1016/j.eti.2020.101243.

Chen W, Zheng H, Guan Q, Teng H, Zhao Chuanliang, Zhao Chun. 2016. Fabricating a Flocculant with Controllable Cationic Microblock Structure: Characterization and Sludge Conditioning Behavior Evaluation. Ind. Eng. Chem. Res..doi:10.1021/acs.iecr.5b04207.

Chhuon R, Shahid MK, Kim S, Choi Y. 2020. Mill scale as a ballasted flocculant for enhancing the settleability of activated sludge. J. Environ. Chem. Eng.doi:10.1016/j.jece.2020.104237.

Curtin K, Steve D, Fitzpatrick B, Meyer P. 2011. Biological Nutrient Removal. Volume ke-4.

Fathiyah N, Pin TG, Saraswati R. 2017. Pola Spasial dan Temporal Total Suspended Solid ( TSS ) dengan Citra SPOT di Estuari Cimandiri , Jawa Barat. Ind. Res. Work. Natl. Semin.(1):518-526.

Harms G, Layton AC, Dionisi HM, Gregory IR, Garrett VM, Hawkins SA, Robinson KG, Sayler GS. 2003. Real-time PCR quantification of nitrifying bacteria in a municipal wastewater treatment plant. Environ. Sci. Technol..doi:10.1021/es0257164.

Jargensen SE, editor. 1979. Chapter 1 Sedimentation. Di dalam: Studies in Environmental Science. Vol. 5. Elsevier. hlm. 1-7.

Kishore N, Gu S. 2010. Wall effects on flow and drag phenomena of spheroid particles at moderate Reynolds numbers. Ind. Eng. Chem. Res.doi:10.1021/ie1011189.

Klidi N, Proietto F, Vicari F, Galia A, Ammar S, Gadri A, Scialdone 0. 2019. Electrochemical treatment of paper mill wastewater by electro-Fenton process. J. Electroanal. Chem. 841(April):166-

171.doi:10.1016/j.jelechem.2019.04.022.
Lee CC, Lin SD. 2007. Handbook of Environmental Engineering Calculations, 2 nd edition.

Mohammed TJ, Shakir E. 2018. Effect of settling time, velocity gradient, and camp number on turbidity removal for oilfield produced water. Egypt. J. Pet..doi:10.1016/j.ejpe.2016.12.006.

Novoa AF, Fortunato L, Rehman ZU, Leiknes TO. 2020. Evaluating the effect of hydraulic retention time on fouling development and biomass characteristics in an algal membrane photobioreactor treating a secondary wastewater effluent. Bioresour. Technol..doi:10.1016/j.biortech.2020.123348.

Qasim SR, Zhu G. 2017. Wastewater treatment and reuse: Theory and design examples: Volume 1: Principles and basic treatment.

Rosidi M, Razif M. 2017. Perancangan Instalasi Pengolahan Air Limbah (IPAL) Industri Kertas Halus. J. Tek. ITS. 6(1):1-4.doi:10.12962/j23373539.v6i1.21802.

Saleh MA, Eziefula AU, Abubakar H, Cynthia 00. 2015. Analysis of Type II Settlement in Water (Flocculent Particles). Int. J. Eng. Mod. Technol. 1(8):16-26.

Samal K, Dash RR. 2021. Modelling of pollutants removal in Integrated Vermifilter (IVmF) using response surface methodology. Clean. Eng. Technol..doi:10.1016/j.clet.2021.100060.

Sarah M. 2005. PROSES REDUKSI EKSES LUMPUR AKTIF DARI IPAL INDUSTRI PEMBUATAN KERTAS. J. Sist. Tek. Ind. 6(3):1-216.

Verma S, Prasad B, Mishra IM. 2011. Thermochemical treatment (thermolysis) of petrochemical wastewater: COD removal mechanism and floc formation. Ind. Eng. Chem. Res..doi:10.1021/ie102576w.

Wu HJ, Bevan MA. 2005. Direct measurement of single and ensemble average particle-surface potential energy profiles. Langmuir..doi:10.1021/la047892r.

Wulandari F. 2007. STRUKTUR DAN KINERJA INDUSTRI KERTAS DAN PULP DI INDONESIA: SEBELUM DAN PASCAKRISIS. 8(2).

Zhou H, Wei C, Zhang F, Hu Y, Wu H, Kraslawski A. 2018. Energy Balance Evaluation in Coking Wastewater Treatment: Optimization and Modeling of Integrated Biological and Adsorption Treatment System. ACS Sustain.

Chem. 